\title{
Sukupuolitettua aikuisoppimista
}

Joanna Ostrouch-Kamińska ja Cristina C. Vieira (toim.) (2015). Private World(s): Gender and Informal Learning of Adults. Sense Publishers, Rotterdam. 194 s. ISBN: 978-946-209-971-5

EUROPEAN SOCIETY FOR RESEARCH on the Education of Adults (ESREA) pyrkii sukupuolen ja aikuisoppimisen tutkimuksen verkostonsa tuoreen tuotoksen kautta herättelemään keskustelua sukupuolesta, informaalin oppimisen teorioista ja elinikäisestä oppimi- sesta nonformaaleissa konteksteissa. Teos markkinoi myös huomioivansa miesnäkökulman.

Kolmentoista erillisen artikkelin 22 kirjoittajan joukosta löytyy uransa eri vaiheissa olevia itä-, keski- ja eteläeurooppalaisia tutkijoita jatko-opiskelijoista emeritaan saakka.
Euroviisutyyliin mukana on australialaisvahvistus, mutta Pohjoismaat loistavat poissaolollaan.

AIKUISTEN OPPIMISEN YKSITYISYYS

Johdantoluvussa sukupuoli määrittyy sosiaaliseksi konstruktioksi, joka 
riippuu ajasta, paikasta ja kulttuurista, ja jota perhe, koulutus, media sekä elämänkokemukset jatkuvasti muokkaavat. Sukupuolentutkimuksen merkitystä perustellaan sen tarjoamilla mahdollisuuksilla "haastaa kriittisesti yksilönvapaudelle turmiollisia sukupuolisia stereotypioita". Teorioista esille nostetaan erityisesti Schugurenskyn ajatukset, joissa informaali oppiminen liitetään hiljaiseen tietoon. Sitä tarkastellaan itseohjautuvuuden, satunnaisuuden ja sosialisaation tasoilla tarkoituksenmukaisuuden ja oppimiskokemuksen aikaisen tietoisuuden näkökulmista. Aikuisille tärkeimmän oppimisen todetaan tapahtuvan arkielämän moninaisten hetkien keskellä, vaihtelevissa konteksteissa ja vuorovaikutustilanteissa.

Teos on ryhmitelty kolmen pääteeman alle. Niistä ensimmäinen pohtii aikuisten informaalin oppimisen sukupuoleen sidottuja epäoikeudenmukaisuuksia yksityisillä elämänpiireillä (private spheres).

Pelkän "naistutkimuksen" kaavasta sanoudutaan irti välittömästi. Lukija kutsutaan pohtimaan 1990-luvun heteronormatiivisen hypermaskuliinisuusdiskurssin vaikutuksia miesten opiskeluhalukkuuteen sodanjälkeisessä Serbiassa, miettimään tuloerojen vaikutuksia parisuhteissa sekä tutustumaan rintasyöpään sairastuneiden miesten kohtaamiin haasteisiin sairautensa tunnistamisessa ja hoidossa. Osion päättää artikkeli vanhojen maalaisnaisten oppimisstrategioista.

Etenkin Astrid Seltrechtin artikkeli rintasyöpään sairastuneista miehistä antaa ajateltavaa. Eettinen linja pitää eikä informanttien kokemuksista revitä lööppejä. Osiota ja koko teosta kokoava aikuisten oppimisen yksityisyyden teema alkaa hahmottua.

\section{VÄHEMMISTÖT JA AKTIVISMI}

Kirjan keskimmäinen osa paneutuu vähemmistöihin ja aktivismiin. Artikkeli ranskalaisen Le Barbe -liikkeen feministinaisista pohtii kansalaisaktivismia oppimisen muotona. Sen vahvuutena on toisen kirjoittajan oma osallistujakokemus tutkitussa liikkeessä. Mezirown teoriapohjasta ammentaen feminististen järjestöjen toimintaperiaatteet rinnastetaan transformatiivisen oppimisen edellytyksiin. Tuloksia on jäsennelty voimautumiskäsitteen nelijaottelun (Oxaal \& Baden 1997) mukaisesti. Aineistossa korostuvat erityisesti sisäinen voima ja voima tehdä, kun vanhempien miesten sekä poliisien ylivaltaa tohditaan vastustaa yhdessä.

Letitia Trifanescun ajankohtainen artikkeli tarkastelee paperittomien naisten kertomuksia lähdöstä, matkasta ja saapumisesta. Trifanesculle maasta- ja maahanmuutto ovat osa yksilön proaktiivista, transformatiivista ja sosiokulttuurista oppimisprosessia, jossa jo lähtöpäätös on voimauttava teko. Naiset ovat tietoisesti paenneet entistä etsiäkseen itselleen ja itsestään jotain uutta. Pakkoavioliiton tilalle löydetty turvallisuus ja toimintavapaus mahdollistavat itsen uudelleenmäärittelyä. Tutkijan korostamat emansipaation, itsenäisyyden ja itsensä toteuttamisen näkökulmat tuntuvat silti hieman päälle liimatuilta.

Teoksen helmeksi paljastuu Barry Goldingin ja Lucia Callaghe- rin kirjoittama luku informaalista oppimisesta "miesten vajoissa" (men's sheds). Sujuva ja mielenkiintoinen artikkeli vertailee ja analysoi etenkin vanhemmille miehille suunnattua äijätoimintaa Australiassa ja Irlannissa sekä tarkastelee naisten roolia toiminnan kulisseissa. Artikkelia voi suositella kaikille miesten aikuiskoulutukseen osallistumattomuutta pohtiville.

\section{INFORMAALI OPPIMINEN}

\section{JA SUKUPUOLI}

Kirjan kolmas osa esittelee informaalin oppimisen erilaisia (non) formaaleja konteksteja portugalilaislähiöstä sosiaalityön oppitunneille ja miesvaltaisilta aloilta yksityisyrityksiin.

"Sukupolvienvälisiä ohjelmia" tarkastelevassa artikkelissa ote aiheesta lipsuu ja kielelliset puutteet vaikeuttavat annin ymmärtämistä. Pääkirjoittajana toiminut jatko-opiskelija olisi ansainnut lisäohjausta.

Malgorzata Ciczkowska-Giedziunin pedagogisesti kiinnostava artikkeli sosiaalityöntekijäopiskelijoiden informaalin oppimisen hyödyntämisestä osana yliopisto-opintoja voi otsikoinnin takia livahtaa ohi alan kouluttajilta. Omien sukupuolisuuteen liittyvien stereotypioiden ja henkilökohtaisten sukupuoliteorioiden työstäminen osana opintoja vaikuttaa mielekkäältä, mutta voitaisiinko alkoholistin tai väkivaltaisen miehen vaimon auttamisen lisäksi pohtia myös ennakkokäsityksiä ravistelevampia vaihtoehtoja kuten alkoholistinaisen puolison auttamista?

Matemaattisluonnontieteellisen alan menestyjänaisten koulutus- ja 
urapolkuja luotaava artikkeli vahvistaa käsitystä vanhempien roolista jälkikasvun uravalinnoissa ja kiinnostanee etenkin ohjausalan ammattilaisia.

Informaalia oppimista työpaikalla käsittelevä luku on pettymys. Mitä esimerkiksi tarkoitetaan "tyypillisellä bulgarialaisella" tai "ulkomaisella" johtamistyylillä ja miksi moinen erottelu oli edes tarpeen tehdä? Lähteitä puuttuu ja kuvioita on liikaa. Aineiston analyysi jää määrien, keskiarvojen ja keskijakaumien varaan. Kirjoittajat itsekin myöntävät analyysin heikkouden ja vihjaavat asian johtuvan työkalun puutteesta. Lukija tulee näin muistutetuksi siitä, että Euroopassakin tutkijat työskentelevät yhä epätasa-arvoisissa olosuhteissa.

\section{TILAA JATKOTUTKIMUKSELLE}

Päätösluvussa toimittajat vetävät lankoja yhteen ja suuntaavat katsetta tulevaan. Sukupuoli auttaa ja vaikeuttaa oman paikan löytämistä yhteiskunnassa, joten stereotyyppisten sukupuoliroolien rajoja ylit- tävillä on enemmän kehittymismahdollisuuksia.

Aikuiskasvatustieteessä tulisi tarkastella sukupuolta naisten ja miesten elämänlaadun parantamiseksi kulttuurista, statuksesta, seksuaalisesta suuntautumisesta tai uskonnosta riippumatta. Tutkimusta olisi tehtävä osallistujien kanssa, ei "heistä". Perinteisten positivististen lähestymistapojen ulkopuolelle jää monia naisten ja miesten kategorioita, joten jatkotutkimukselle on tilaa.

Paikoitellen teos on todella antoisaa luettavaa, ajoittain asiasta on vaikea saada kiinni häiriötekijöiden vuoksi. Sisällöllisesti teos tarjoaa oivaltavia näkökulmia ja monipuolistaa kuvaa sukupuolen tutkimuksen ulottuvuuksista aikuisoppijoiden maailmoissa. Sukupuolisuuden merkitystä havainnoidaan erityisesti tilanteissa, joissa perinteiset sukupuolirajat "yllättäen" ylittyvät sekä kulloisenkin kontekstin "tavallisen" tavallisuudessa.

Teos olisi kaivannut vahvempaa editointia ja perusteellisempaa loppusilmäystä. Markkinoitu miesnäkökulmakin jää kolmen artikkelin ja mieskirjoittajan panostuksella ohueksi.

Riviensä välissä teos on kuva tieteellisen kirjoittamisen nykyarjesta, jossa kukin tekee osansa tahollaan eikä yhtenäistä kieliasua aina löydetä edes saman artikkelin sisällä. Äidinkielenään englantia puhumattomilla ei välttämättä ole käytössään kielenhuoltopalveluja eikä toimittajien aika riitä lähdeluettelojen tarkastamiseen tai kuvioiden sävyerotteluista huolehtimiseen. Artikkeleja kirjoitetaan osa-aineistoilla tai tilastopohjalta, koska ajateltua empiriaa ei ehdittykään tehdä.

Osittain ontuvasta toteutuksesta huolimatta asetettu päätavoite saavutetaan ja kuva sukupuolentutkimuksesta aikuisoppimisen kentillä avartuu. Samalla teos tarjoaa monenlaisia rajoja ylittäviä ja elämänmakuisia kohtaamisia.

Katinka Käyhkö

KM, projektikoordinaattori Finnish University Partnership for International Development (UniPID) Jyväskylän yliopisto 